\title{
molecules
}

ISSN 1420-3049

www.mdpi.com/journal/molecules

Article

\section{Antifungal Activities of New Coumarins}

Ahmed A. Al-Amiery ${ }^{1,2, *}$, Abdul Amir Hassan Kadhum ${ }^{1}$ and Abu Bakar Mohamad ${ }^{1}$

1 Chemical Engineering Faculty, University of Kabengassan Malaysia (UKM), Selangor 43000, Malaysia

2 Applied Chemistry division, Applied Science Department, University of Technology (UOT), Baghdad 10066, Iraq

* Author to whom correspondence should be addressed; E-Mail: dr.ahmed1975@gmail.com; Tel.: +6-0-192-903-670.

Received: 31 March 2012; in revised form: 12 April 2012 / Accepted: 20 April 2012 /

Published: 14 May 2012

\begin{abstract}
Newly synthesized coumarins 4-((5-mercapto-4-phenyl-4H-1,2,4-triazol-3-yl)methoxy)-2H-chromen-2-one and 4-((5-(phenylamino)-1,3,4-thiadiazol-2-yl)-methoxy)$2 \mathrm{H}$-chromen-2-one were tested against selected types of fungi and showed significant activities. DFT calculations of the synthesized coumarins were performed using molecular structures with optimized geometries. Molecular orbital calculations provide a detailed description of the orbitals, including spatial characteristics, nodal patterns, and the contributions of individual atoms.
\end{abstract}

Keywords: antifungal; 4-aminoantipyrine; benzyl bromide; coumarins; DFT; ethyl bromoacetate; 4-hydroxycoumarin

\section{Introduction}

The serious medical problem of bacterial and fungal resistance and the rapid rate at which it develops has led to increasing levels of resistance to classical antibiotics [1-3], and the discovery and development of effective antibacterial and antifungal drugs with novel mechanisms of action have thus become urgent tasks for infectious disease research programs [4,5]. Coumarin and its derivatives represent one of the most active classes of compound possessing a wide spectrum of biological activity [6-12]. The interesting biological activity of these coumarins made these compounds attractive targets in organic synthesis. Several synthetic strategies for the synthesis of coumarins have already 
been developed. Coumarins can be synthesized by the Perkin reaction, Pechmann reaction or by Knoevenagel condensation of salicylaldehydes with malonic acid, or Meldrum's acid [13]. malonic esters, cyanoacetic esters. Recently, the Wittig reaction in $\mathrm{N}, \mathrm{N}$-diethylaniline was also conveniently applied for the synthesis of coumarins [14]. The preparation of ethyl 2-(2-oxo-2H-chromen-4-yloxy)acetate (2), which was used as a starting material for the synthesis of compounds $\mathbf{5}$ and $\mathbf{7}$, is presented in this study. The chemical structures of the synthesized compounds 2-7 were determined and confirmed. The in vitro antifungal activities of the synthesized compounds 5 and 7 were investigated.

Structure activity relationships of coumarin derivatives have revealed that the presence of substituted amino derivatives is an essential feature of their pharmacological action. Based on these findings, we try to describe the synthesis of some compounds featuring different heterocyclic rings fused onto the coumarin moiety with the aim of obtaining more potent pharmacologically active compounds.

\section{Results and Discussion}

\subsection{Chemistry}

For the synthesis of new coumarins $\mathbf{2}-\mathbf{7}$, the reaction sequence is out lined in Scheme 1, started from 4-hydroxycoumarins $\mathbf{1}$.

Scheme 1. Reaction sequences of the synthesized compounds.

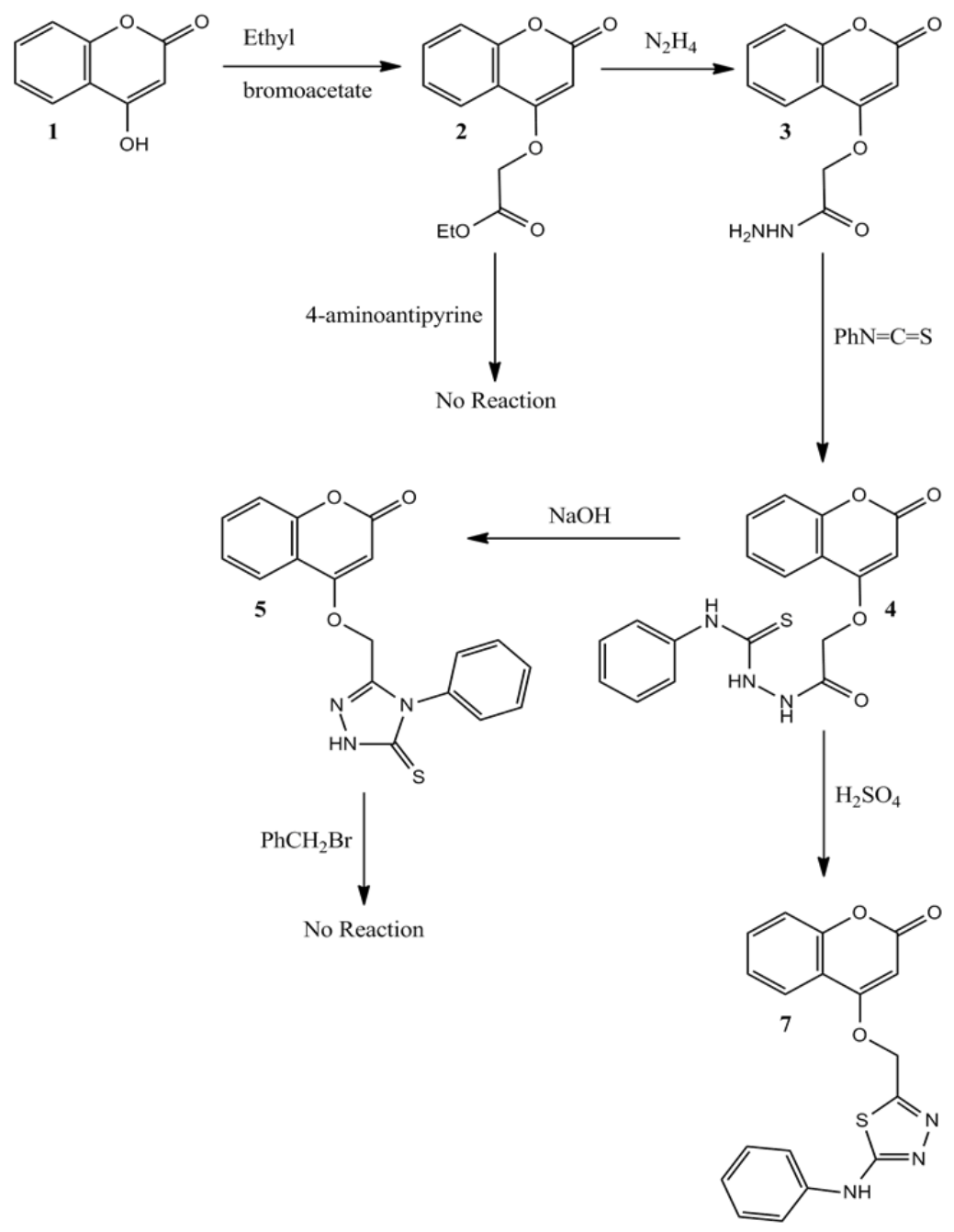


Compound 2, (ethyl 2-(2-oxo-2H-chromen-4-yloxy) acetate) was obtained by the reflux of ethyl bromoacetate with 4-hydroxycoumarin (1) in the presence of anhydrous potassium carbonate in anhydrous acetone. Reaction of compound 2, with various amines was very difficult, even when different solvents (methanol, ethanol and acetone) were used and only hydrazine reacted with compound 2. Hydrazinolysis of compound $\mathbf{2}$ with hydrazine hydrate afforded hydrazide $\mathbf{3}$ in good yield. The FT-IR spectrum of compound 3 showed absorption bands in the $3297.3,3211.0 \mathrm{~cm}^{-1}$ (hydrazide $\mathrm{NH}-\mathrm{NH}_{2}$ ), $1671 \mathrm{~cm}^{-1}$ (lactonic-C=O carbonyl stretching), and $1,711.5 \mathrm{~cm}^{-1}$ (esteric-C $=\mathrm{O}$ carbonyl stretching). The ${ }^{1} \mathrm{H}-\mathrm{NMR}$ spectrum exhibited a singlet due to the $-\mathrm{CO}-\mathrm{NH}-\mathrm{NH}_{2}$ proton at $\delta$ $8.89 \mathrm{ppm}$. Compound $\mathbf{3}$ was allowed to react with isothiocyanatobenzene to yield compound $\mathbf{4}$ that can be cyclized either with sodium hydroxide to yield compound 5 that cannot react with benzyl bromide, or cyclized with sulphuric acid to yield compound 7. For compound 4, the IR spectrum has the following characteristic absorption bands: $v_{\mathrm{N}-\mathrm{H}}\left(3368.9,3371,3350,3262 \mathrm{~cm}^{-1}\right) ; v_{\mathrm{C}=\mathrm{O}}$ (1760 lactone; 1686 ester $\left.\mathrm{cm}^{-1}\right), v_{\mathrm{C}=\mathrm{S}}\left(1276 \mathrm{~cm}^{-1}\right)$. In the IR spectrum of compound 7, no absorption band was detected about $1700 \mathrm{~cm}^{-1}$ indicating the absence of the ester carbonyl group, which is evidence for the conversion of compound 4 to compound 7. Also, in the IR spectrum of the new heterocyclic compound 7 a stretching band characteristic of the $\mathrm{C}=\mathrm{N}$ group from heterocyclic nucleus was seen at $1599 \mathrm{~cm}^{-1}$ (from thiadiazole). Although two types of tautomers, thione or thiole (Scheme 2), could be expected from the cyclization of compound $\mathbf{5}$, under basic media, only the thione type compound $\mathbf{5}$ was observed. Existence of the thione form predominantly in the solid state is demonstrated by the presence of two absorption bands at $1240 \mathrm{~cm}^{-1}$ and $3408 \mathrm{~cm}^{-1}$ belonging to the $v_{\mathrm{C}=\mathrm{S}}$ and $v_{\mathrm{NH}}$ groups, respectively, and by absence of $v_{\mathrm{SH}}$ [15]. Reaction of compound 2 with 4-aminoantipyrine was not successful, even when we use dimethyformamide as solvent, moreover no product was formed when we try to react compound $\mathbf{5}$ with benzyl bromide.

Scheme 2. Tautomerization of compound 5.
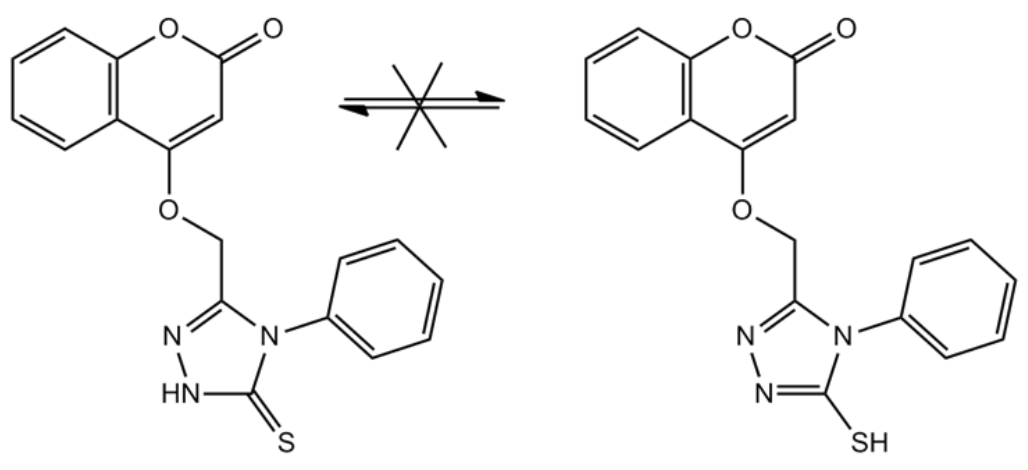

\subsection{Computational Studies}

\subsubsection{Atomic Charges and Stabilities}

The theoretical studies for compound $\mathbf{5}$ revealed that the atomic charges have been affected by the presence of the ring substituent. The minimized geometry is shown in Figure 1, where the calculated atomic charges for the compounds $\mathbf{5}$ and $\mathbf{7}$ are also indicated. For compound $\mathbf{5}$ the highest atomic charge is at $[\mathrm{O}(3)-0.57)]$ and the next charge values are at $[\mathrm{N}(18)-0.512]$ and $[\mathrm{S}(19)-0.38]$. These results clearly indicated that these three atoms are the most reactive sites toward the reactions and 
bonding with the metals. The calculated bond and twist angles and 3D-geometrical structure, indicated that this molecule is not planar moreover the stereochemistry is $\mathrm{C}(5)-\mathrm{C}(4)$ : (E) and $\mathrm{N}(18)-\mathrm{C}(14)$ : (Z). The $\mathrm{C}(13)-\mathrm{C}(14)$ bond length is 1.4970 ; $\mathrm{O}(12)-\mathrm{C}(13)$ is 1.4020 and $\mathrm{C}(5)-\mathrm{O}(12)$ is 1.3550.

For compound 7 the highest atomic charge is at $[\mathrm{O}(11)-0.805)]$ and the next charge value is at $[C(2)-0.433]$. These results clearly indicated that these atoms are the most reactive sites toward the reactions and bonding with the metals. The calculated bond and twist angles and 3d-geometrical structure, indicated that this molecule is not planar moreover the stereochemistry is $\mathrm{C}(3)-\mathrm{C}(2)$ : $(E)$. The $\mathrm{S}(14)-\mathrm{C}(18)$ bond length is 1.7159 ; $\mathrm{S}(14)-\mathrm{C}(15)$ is $1.7158 ; \mathrm{C}(18)-\mathrm{C}(19)$ is 1.2660 and $\mathrm{C}(20)-\mathrm{C}(19)$ is 1.2660 .

Figure 1. 3D-geometrical structures for compounds 5 and 7.
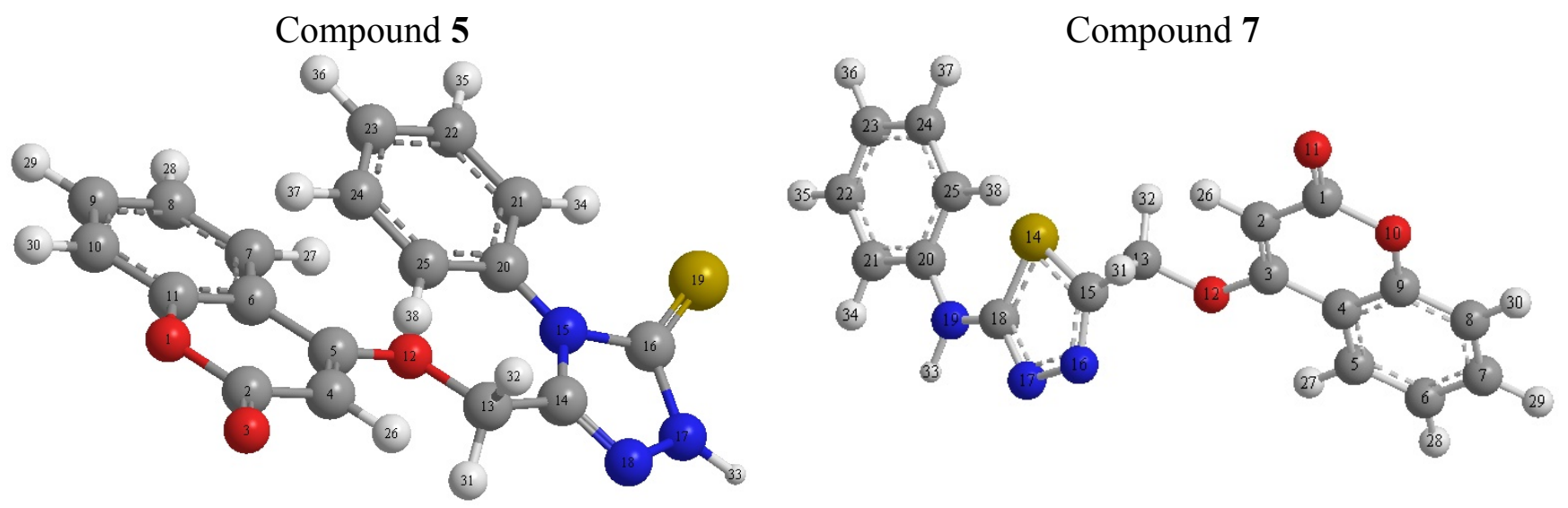

\subsubsection{Density Function Theory (DFT)}

DFT calculations were performed for compound 5. The optimized molecular structures of the most stable forms are shown in Figure 1. Molecular orbital calculations provide a detailed description of orbitals including spatial characteristics, nodal patterns and individual atom contributions. The contour plots of the frontier orbitals for the ground state of $\mathbf{5}$ and $\mathbf{7}$ are shown in Figures 2 and 3, including the Highest Occupied Molecular Orbital (HOMO) and the Lowest Unoccupied Molecular Orbital (LUMO). It is interesting to see that both orbitals are substantially distributed over the conjugation plane. It can be seen from Figures 2 and 3 that the HOMO orbitals are located on the substituted molecule while LUMO orbitals resemble those obtained for the unsubstituted molecule and therefore the substitution has an influence on the electron donation ability, but only a small impact on electron acceptance ability [16-18]. The orbital energy levels of HOMO and LUMO of compound 5 and 7 are listed in Table 1. It can be seen that the energy gaps between HOMO and LUMO is about $2.241 \mathrm{eV}$. for compound 5, and the lower value in the HOMO and LUMO energy gap explain the eventual charge transfer interaction taking place within the molecules.

For compound 7, the energy gap between HOMO and LUMO is about $-2.570 \mathrm{eV}$. The lower value of the HOMO and LUMO energy gap explains the eventual charge transfer interaction taking place within the molecules. 
Figure 2. HOMO, LUMO, HOMO -1 and LUMO +1 orbitals of 5.
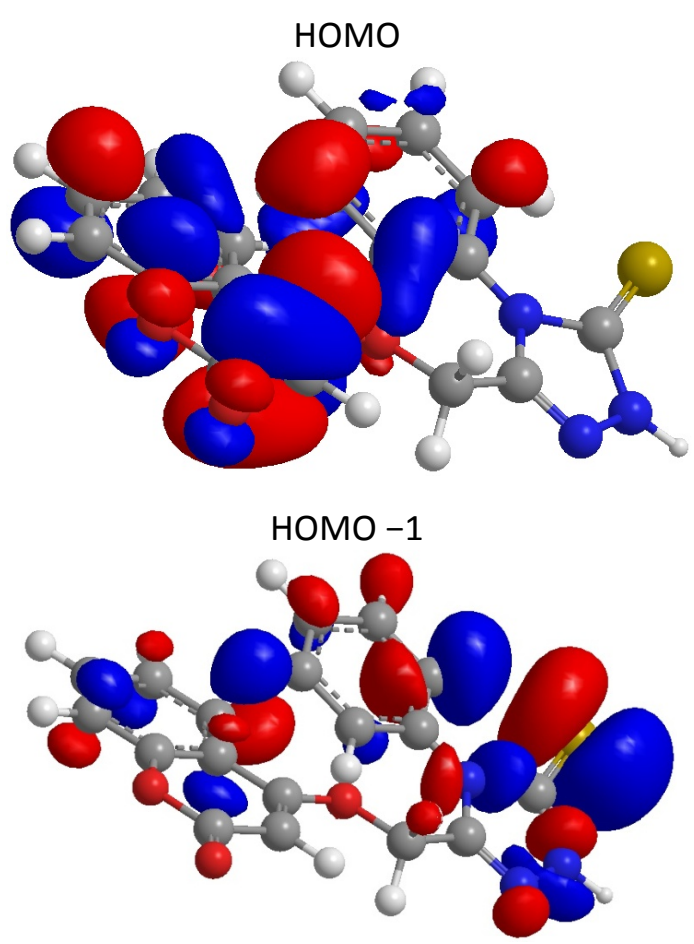

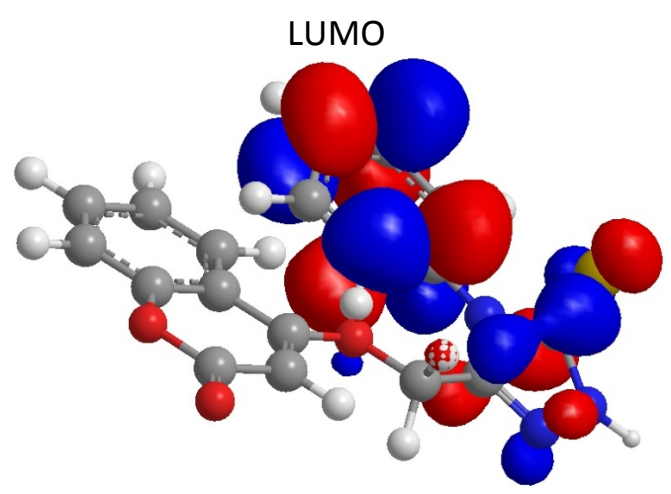

LUMO +1

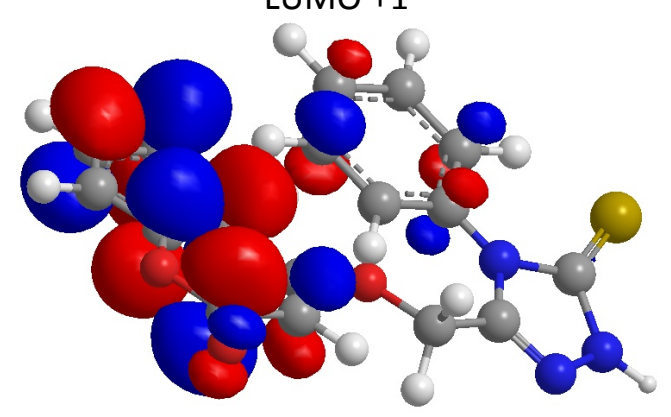

Figure 3. HOMO, LUMO, HOMO -1 and LUMO +1 orbitals of 7.

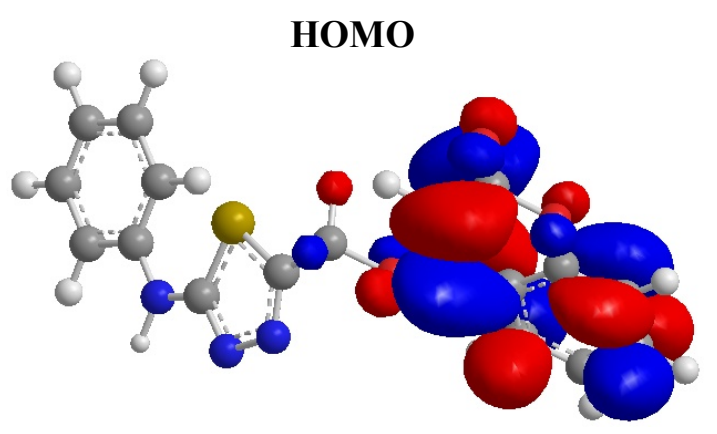

HOMO

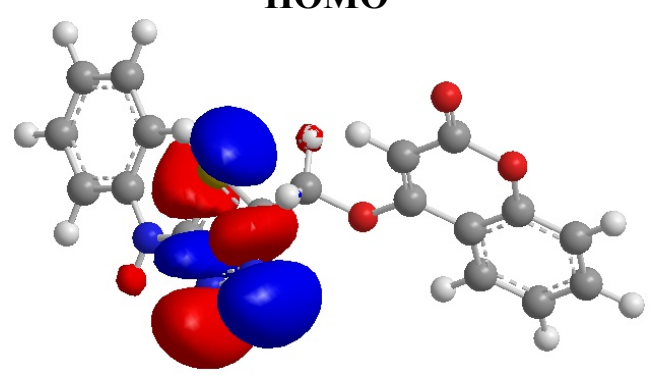

LUMO

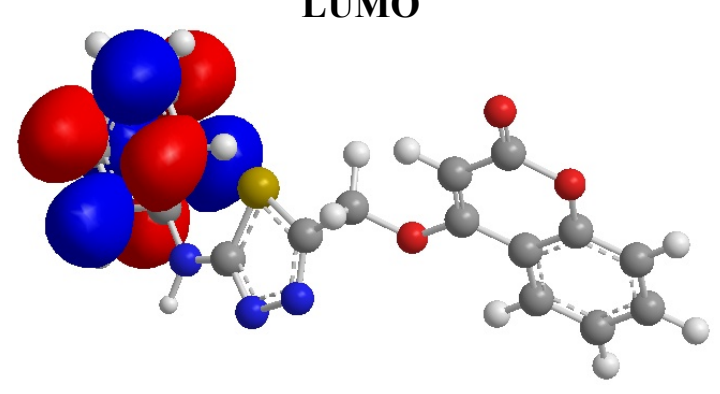

LUMO

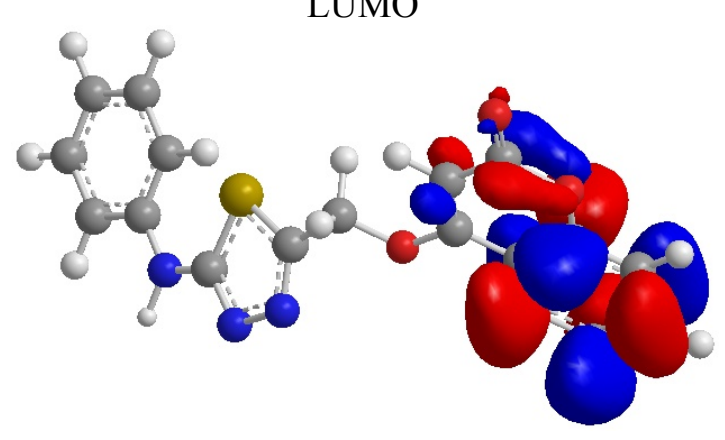

Table 1. HOMO and LUMO energies of 5 and $7(\mathbf{e V})$.

\begin{tabular}{cccccc}
\hline HOMO & LUMO & $\Delta \mathbf{E}$ & HOMO -1 & LUMO +1 & $\Delta \mathbf{E}$ \\
\hline-2.840 & -0.599 & -2.241 & -6.415 & -0.205 & -6.210 \\
\hline-3.625 & -1.055 & 2.570 & -8.830 & -0.067 & 8.763 \\
\hline
\end{tabular}




\subsection{Antifungal Activity}

According to Overtone's concept of cell permeability, the lipid membrane that surrounds the cell favors the passage of only lipid-soluble materials, so lipophilicity is an important factor controlling the antifungal activity. Delocalization of $\pi$-electrons over the compounds 5 and 7 increases lipophilicity which in turn facilitates the penetration of the compounds 5 and 7 into lipid membranes, further restricting proliferation of the microorganisms. Although the exact biochemical mechanism is not completely understood, the mode of action of antimicrobials may involve various targets in the microorganisms:

- Interference with the synthesis of cellular walls, causing damage that can lead to altered cell permeability characteristics or disorganized lipoprotein arrangements, ultimately resulting in cell death.

- Deactivation of various cellular enzymes that play a vital role in the metabolic pathways of these microorganisms.

- Denaturation of one or more cellular proteins, causing the normal cellular processes to be impaired.

- Formation of a hydrogen bond through the azomethine group with the active centers of various cellular constituents, resulting in interference with normal cellular processes [19-24].

In vitro antifungal screening effects of the investigated compounds $\mathbf{5}$ and $\mathbf{7}$, were tested against some fungal spices (Aspergillus niger and Candida albicans). Compounds $\mathbf{5}$ and $\mathbf{7}$ showed good activities as antifungals compared to the antifungal ability of fluconazole, which was used as a standard (Figures 4 and 5).

Figure 4. The effect of compounds 5 and 7 towards the tested organism Aspergillus niger.

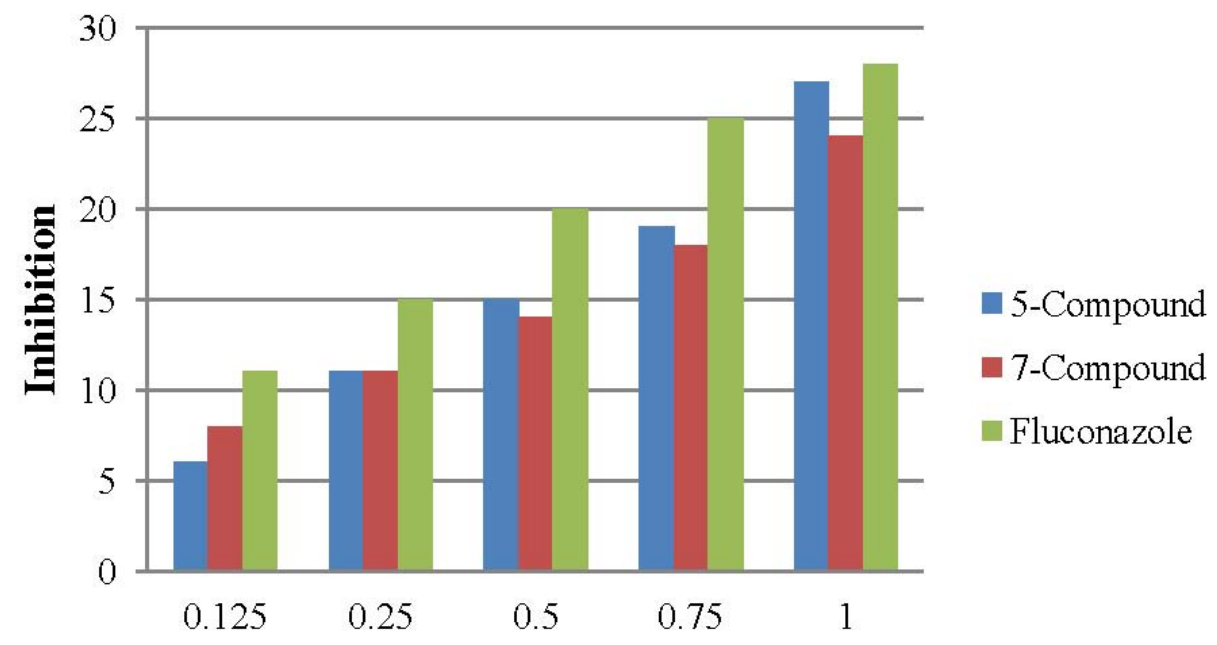

Concentrations $\mu \mathrm{g} / \mathrm{mL}$ 
Figure 5. The effect of compounds 5 and $\mathbf{7}$ toward the tested organism Candida albicans.

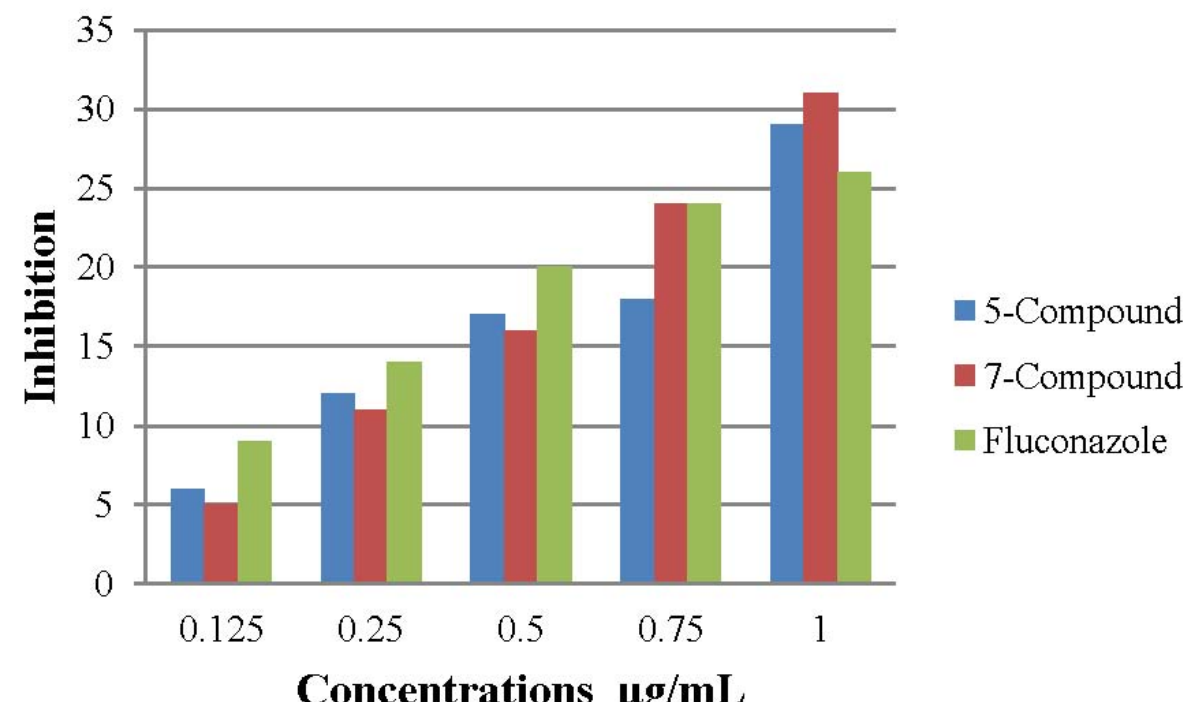

\section{Experimental}

\subsection{General}

The chemicals used during synthesis was supplied by Sigma-Aldrich. Purity of the compounds was checked on thin layer chromatography (TLC) plates (Silica gel G) in the solvent systems benzene-ethyl acetate-methanol $(40: 30: 30, \mathrm{v} / \mathrm{v} / \mathrm{v})$ and toluene-acetone $(75: 25, \mathrm{v} / \mathrm{v})$. The spots were located under 254 and $365 \mathrm{~nm}$ UV light. The IR spectra was obtained on a Thermo Scientific, NICOLET 6700 FTIR spectrometer (without out KBr or CsI pellets), at the Faculty of Engineering. The NMR spectra was obtained on a JEOL JNM-ECP 400, FT-NMR system at UKM, Faculty of Science Technology (FST), Chemistry Department. Elemental microanalysis, was carried out using a model 5500-Carlo Erba C.H.N elemental analyzer. A Gallenkamp M.F.B.600.010 F melting point apparatus was used to measure the melting points of all the prepared compounds.

\subsubsection{Ethyl 2-((2-oxo-2H-chromen-4-yl)oxy)acetate (2)}

A suspension of 4-hydroxycoumarin $(1,6.17 \mathrm{mmol})$ in acetone $(30 \mathrm{~mL})$ was refluxed with ethyl bromoacetate $(9.15 \mathrm{mmol})$ and $\mathrm{K}_{2} \mathrm{CO}_{3}(4.69 \mathrm{~g}, 33.91 \mathrm{mmol})$ for $12 \mathrm{~h}$. After cooling, the mixture was evaporated to dryness and the residue was partitioned between $\mathrm{CHCl}_{3}(50 \mathrm{~mL})$ and water $(50 \mathrm{~mL})$. The organic phase was dried $\left(\mathrm{Na}_{2} \mathrm{SO}_{4}\right)$, filtered and evaporated to dryness. The residue was recrystallized from acetone; yield 92\%; m.p. $99.0{ }^{\circ} \mathrm{C} ;{ }^{1} \mathrm{H}-\mathrm{NMR}\left(\mathrm{CDCl}_{3}\right): \delta 3.22\left(\mathrm{t}, 3 \mathrm{H}, \mathrm{CH}_{3}\right), \delta 3.85\left(\mathrm{~m}, 2 \mathrm{H}, \mathrm{CH}_{2}\right), \delta$ $4.91(\mathrm{~s}, 2 \mathrm{H})$ and $\delta 5.20, \delta 5.250, \delta 5.272(\mathrm{~s}, 2 \mathrm{H})$ for $\left.\mathrm{CH}_{2}\right), \delta 5.78(\mathrm{~s}, 1 \mathrm{H})$ for $\left.-\mathrm{C}=\mathrm{C}-\mathrm{H}\right), \delta 7.291, \delta 7.478$, $\delta 7.80(\mathrm{~s}, 1 \mathrm{H})$ for aromatic ring); ${ }^{13} \mathrm{C}-\mathrm{NMR}: 167.2 ; 165.1 ; 163.4,155.9 ; 134.2 ; 121.8 ; 121.1 ; 119.0$; 113.8; 100.9; 65.3; 54.7; 22.12; IR: $2987.3 \mathrm{~cm}^{-1}$ (C-H, aliphatic), $3089.5 \mathrm{~cm}^{-1}$ (C-H, aromatic), $1759.3 \mathrm{~cm}^{-1}(\mathrm{C}=\mathrm{O}$, lactone $), 1717.6 \mathrm{~cm}^{-1}(\mathrm{C}=\mathrm{O}$, ester $), 1629.2 \mathrm{~cm}^{-1}(\mathrm{C}=\mathrm{C}$, alkene $), 1577.6 \mathrm{~cm}^{-1}(\mathrm{C}=\mathrm{C}$, aromatic). 


\subsubsection{2-(2-Oxo-2H-chromen-4-yloxy)acetohydrazide (3)}

A solution of compound $2(10 \mathrm{mmol})$ in ethanol $(25 \mathrm{~mL})$ was refluxed with hydrazine hydrate (15 mmol) for $4 \mathrm{~h}$. After concentrating the reaction mixture a solid mass separated out and recrystallized using ethanol, yield 51\%, m.p. $228{ }^{\circ} \mathrm{C} ;{ }^{1} \mathrm{H}-\mathrm{NMR}\left(\mathrm{CDCl}_{3}\right): \delta 4.48\left(\mathrm{~s}, 2 \mathrm{H}, \mathrm{CH}_{2}\right), \delta 4.65(\mathrm{~s}$, $\left.2 \mathrm{H}, \mathrm{NH}_{2}\right), \delta 8.89(\mathrm{~s}, 1 \mathrm{H}, \mathrm{NH}), \delta 4.92(\mathrm{~s}, 2 \mathrm{H})$ and $\delta 5.210(\mathrm{~s}, 2 \mathrm{H})$ for $\left(\mathrm{O}-\mathrm{CH}_{2}\right), \delta 5.72(\mathrm{~s}, 1 \mathrm{H})$ for $(-\mathrm{C}=\mathrm{C}-\mathrm{H}), \delta 7.410, \delta 7.521, \delta 8.10(\mathrm{~s}, 1 \mathrm{H})$ for aromatic ring; IR: $3297.3,3211 \mathrm{~cm}^{-1}(\mathrm{~N}-\mathrm{H})$, $2906.0 \mathrm{~cm}^{-1}$ (C-H, aliphatic), $3072.7 \mathrm{~cm}^{-1}\left(\mathrm{C}-\mathrm{H}\right.$, aromatic), $1711.5 \mathrm{~cm}^{-1}(\mathrm{C}=\mathrm{O}), 1671.2 \mathrm{~cm}^{-1}(\mathrm{C}=\mathrm{O}$,

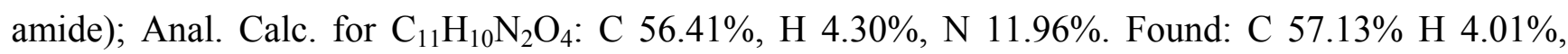
$\mathrm{N} 10.52 \%$.

\subsubsection{2-(2-(2-Oxo-2H-chromen-4-yloxy)acetyl)-N-phenylhydrazinecarbothioamide (4)}

A mixture of hydrazide $3(2 \mathrm{mmol})$ and phenyl isothiocyanate $(2 \mathrm{mmol})$ in ethanol $(15 \mathrm{~mL})$ was refluxed for $12 \mathrm{~h}$. The reaction mixture was cooled and the separated product was filtered off, dried and recrystallized, using ethanol, yield $88 \%$, m.p. $189-192{ }^{\circ} \mathrm{C} ;{ }^{1} \mathrm{H}-\mathrm{NMR}\left(\mathrm{CDCl}_{3}\right): \delta 4.48\left(\mathrm{~s}, 2 \mathrm{H}, \mathrm{CH}_{2}\right)$, $\delta 5.12\left(\mathrm{~s}, 2 \mathrm{H}, \mathrm{NH}_{2}\right), \delta 8.64(\mathrm{~s}, 1 \mathrm{H}, \mathrm{NH}), \delta 4.80(\mathrm{~s}, 2 \mathrm{H})$ and $\delta 5.35(\mathrm{~s}, 2 \mathrm{H})$ for $\left(\mathrm{O}-\mathrm{CH}_{2}\right), \delta 5.71(\mathrm{~s}, 1 \mathrm{H})$ for $(-\mathrm{C}=\mathrm{C}-\mathrm{H}), \delta 7.41, \delta 7.32, \delta 7.92(\mathrm{~s}, 1 \mathrm{H})$ for aromatic ring; IR: $3368.9,3371,3350,3262 \mathrm{~cm}^{-1}$ $(\mathrm{N}-\mathrm{H}), 2929.0 \mathrm{~cm}^{-1}$ (C-H, aliphatic), $3074.6 \mathrm{~cm}^{-1}$ (C-H, aromatic), $1760.5 \mathrm{~cm}^{-1}$ (C=O, lactone), $1686.5 \mathrm{~cm}^{-1}(\mathrm{C}=\mathrm{O}), 1276.7(\mathrm{C}=\mathrm{S})$; Anal. Calc. for $\mathrm{C}_{15} \mathrm{H}_{18} \mathrm{~N}_{3} \mathrm{O}_{4} \mathrm{~S}: \mathrm{C} 58.53 \%, \mathrm{H} \mathrm{4.09 \% ,} \mathrm{N} \mathrm{11.38 \% .}$ Found: C 57.98\% H 4.36\%, N 10.93\%.

\subsubsection{4-((5-Mercapto-4-phenyl-4H-1,2,4-triazol-3-yl)methoxy)-2H-chromen-2-one (5)}

Compound $4(0.5 \mathrm{mmol})$ was added to $8 \% \mathrm{NaOH}$ solution $(4 \mathrm{~mL})$ and the reaction mixture was heated under reflux for $4 \mathrm{~h}$. After cooling, the solution was acidified with a diluted solution of $\mathrm{HCl}$. Crude product was precipitated, filtered off and washed with water. The solid thus separated was dried and recrystallized using chloroform-ether (1:1, v/v), yield 55\%, m.p. $247-251{ }^{\circ} \mathrm{C} ;{ }^{1} \mathrm{H}-\mathrm{NMR}\left(\mathrm{CDCl}_{3}\right): \delta$ 4.77 and $5.40\left(\mathrm{~d}, 2 \mathrm{H}, \mathrm{OCH}_{2}\right), \delta 5.81(\mathrm{~s}, 1 \mathrm{H})$ for $(-\mathrm{C}=\mathrm{C}-\mathrm{H}), \delta 7.221-7.71(\mathrm{~m}, 1 \mathrm{H})$ for aromatic ring; IR: $3408 \mathrm{~cm}^{-1}(\mathrm{~N}-\mathrm{H}), 2892.3 \mathrm{~cm}^{-1}$ (C-H, aliphatic), $3076.3 \mathrm{~cm}^{-1}\left(\mathrm{C}-\mathrm{H}\right.$, aromatic), $1758.29 \mathrm{~cm}^{-1}(\mathrm{C}=\mathrm{O}$, lactone), $1577.8 \mathrm{~cm}^{-1}(\mathrm{C}=\mathrm{N}), 1634.2 \mathrm{~cm}^{-1}(\mathrm{C}=\mathrm{C})$ and $1240 \mathrm{~cm}^{-1}(\mathrm{C}=\mathrm{S})$. Anal Calc.for $\mathrm{C}_{18} \mathrm{H}_{13} \mathrm{~N}_{3} \mathrm{O}_{3} \mathrm{~S}$ : C $61.53 \%$, H 3.73\%, N 11.96\%. Found: C 60.91\% H .3.98\%, N $11.14 \%$.

\subsubsection{4-((5-(Phenylamino)-1,3,4-thiadiazol-2-yl)methoxy)-2H-chromen-2-one (7)}

A mixture of compound $4(0.15 \mathrm{mmol})$ and concentrated $\mathrm{H}_{2} \mathrm{SO}_{4}(5 \mathrm{~mL})$ was stirred in an ice bath for $5 \mathrm{~h}$ and then at room temperature for another $5 \mathrm{~h}$. The reaction mixture was neutralized with a diluted solution of ammonium hydroxide, in an ice bath. The precipitate was filtered off, washed with water, dried and recrystallized. using chloroform-ether $(1: 1, \mathrm{v} / \mathrm{v})$, yield $65 \%$, m.p. $240-242{ }^{\circ} \mathrm{C}$; ${ }^{1} \mathrm{H}-\mathrm{NMR}\left(\mathrm{CDCl}_{3}\right): \delta 4.96$ and $5.35\left(\mathrm{~d}, 2 \mathrm{H}, \mathrm{OCH}_{2}\right), \delta 5.80(\mathrm{~s}, 1 \mathrm{H})$ for $(-\mathrm{C}=\mathrm{C}-\mathrm{H}), \delta 7.21-8.02(\mathrm{~m}, 1 \mathrm{H})$ for aromatic ring; IR: $2900.1 \mathrm{~cm}^{-1}\left(\mathrm{C}-\mathrm{H}\right.$, aliphatic), $3079.7 \mathrm{~cm}^{-1}\left(\mathrm{C}-\mathrm{H}\right.$, aromatic), $1761.7 \mathrm{~cm}^{-1}(\mathrm{C}=\mathrm{O}$, lactone), $1626.0 \mathrm{~cm}^{-1}(\mathrm{C}=\mathrm{C}), 1599.7 \mathrm{~cm}^{-1}(\mathrm{C}=\mathrm{N}) \mathrm{cm}^{-1}$ Anal. Calc. for $\mathrm{C}_{18} \mathrm{H}_{13} \mathrm{~N}_{3} \mathrm{O}_{3} \mathrm{~S}: \mathrm{C} 61.53 \%, \mathrm{H}$ $3.73 \%$, N $11.96 \%$. Found: C 61.01\% H 4.02\%, N 11.13\%. 


\subsection{DFT}

Gaussian 03, Revision C.01 was used for the calculation of ground-state geometry that was optimized to a local minimum without any symmetry restrictions using the $3-21 \mathrm{G}$ basis set. The Becke three-parameter hybrid (B3) exchange functional in combination with the Lee-Yang-Parr (LYP) correction functional (B3LYP) was used for all geometry optimizations, thermodynamic functions at standard conditions (temperature $=298.150$ Kelvin, and pressure $=1.0$ Atm), High Occupied Molecular Orbital (HOMO) and Low Unoccupied Molecular Orbital (LUMO) distribution, and some physical properties for all molecules.

\subsection{Evaluation of Antifungal Assay}

Antifungal activity [25,26], was determined based on the growth inhibition rates of the mycelia of strains (Aspergillus niger and Candida albicans) in Potato Dextrose Broth medium (PDB). Under aseptic conditions, one $\mathrm{mL}$ of spore suspension $(5 \times 106 \mathrm{cfu} / \mathrm{mL})$ of tested fungi was added to $50 \mathrm{~mL}$ PDB medium in a $100 \mathrm{~mL}$ Erlenmeyer flask. Appropriate volumes of tested compounds $\mathbf{5}$ and $\mathbf{7}$ were added to produce concentrations ranging from 10 to $100 \mu \mathrm{g} \mathrm{mL} \mathrm{L}^{-1}$. Flasks were incubated at $27 \pm 1{ }^{\circ} \mathrm{C}$ in the dark for 5 days and then the mycelium was collected on filter papers. The filter papers were dried to constant weight and the level of inhibition, relative to the control flasks was calculated from the following formula:

$$
\text { Percentage of inhibition }=\frac{\mathrm{C}-\mathrm{T}}{\mathrm{C}} \times 100
$$

where $\mathrm{T}=$ weight of mycelium from test flasks and $\mathrm{C}=$ weight of mycelium from control flasks.

\section{Conclusions}

In this study, the compounds 2-7 were synthesized, and characterized using various spectroscopic methods and elemental analysis. The synthesized compounds $\mathbf{5}$ and $\mathbf{7}$ were studied theoretically and their atomic charges, heat of formation and stereochemistry were estimated, and it was found that they are not planar. The synthesized compounds $\mathbf{5}$ and $\mathbf{7}$ were tested for antifungal activities and indicated significant antifungal activities as compared with fluconazole.

\section{References and Notes}

1. Rice, S.A.; Givskov, M.; Steinberg, P.; Kjelleberg, S. Bacterial signals and antagonists: The interaction between bacteria and higher organisms. J. Mol. Microbiol. Biotechnol. 1999, 1, $23-31$.

2. Ironmonger, A.; Whittaker, B.; Andrew, J.; Baron, B.; Chris, J.; Alison, E.; Ashcroft, G.; Nelson, A. Scanning conformational space with a library of stereo- and regiochemically diverse aminoglycoside derivatives: The discovery of new ligands for RNA hairpin sequences. Org. Biomol. Chem. 2007, 5, 1081-1086.

3. Al-Amiery, A.A.; Mohammed, A.; Ibrahim, H.; Abbas, A. Study the biological activities of tribulus terrestris extracts. World Acad. Sci. Eng. Technol. 2009, 57, 433-435. 
4. Kumar, G.; Kumar, D.; Devi, S.; Verma, R.; Johari, R. Synthesis, spectral characterization of biologically active compounds derived from oxalyldihydrazide and 5-tert-butyl-2-hydroxy-3-(3phenylpent-3-yl)benzaldehyde and their $\mathrm{Cu}(\mathrm{II}), \mathrm{Ni}(\mathrm{II})$ and $\mathrm{Co}(\mathrm{II})$ Complexes. Int. J. Eng. Sci. Technol. 2011, 3, 1630-1635.

5. Kadhum, A.H.; Mohamad, A.; Al-Amiery, A.A. Antimicrobial and anti-oxidant activities of new metal complexes derived from 3-aminocoumarin. Molecules 2011, 16, 6969-6984.

6. El-Agrody, A.; Abd El-Latif1, M.; El-Hady, N.; Fakery A.; Bedair, A. Hetero aromatization with 4-ydroxycoumarin Part II: Synthesis of some new pyrano[2,3- $d]$ pyrimidines, $[1,2,4]$ triazolo [1,5-c]pyrimidines and Pyrimido[1,6-b] [1,2,4]triazine derivatives. Molecules 2001, 6, 519-527.

7. Rositca, D.N.; Vayssilov, G.N.; Rodios, N.; Bojilova, A. Regio- and Stereoselective $[2+2]$ Photodimerization of 3-Substituted 2-Alkoxy-2-oxo-2H-1,2-benzoxaphosphorines. Molecules 2002, 7, 420-432.

8. Al-Amiery, A.A.; Al-Bayati, R.; Saour, K.; Radi, M. Cytotoxicity, Antioxidant and Antimicrobial activities of novel 2-quinolone derivatives derived from coumarins. Res. Chem. Intermed. 2011, 38, 559-569.

9. Al-Amiery, A.A.; Musa, A.Y.; Kadhum, A.H.; Mohamad, A. The use of umbelliferone in the synthesis of new heterocyclic compounds. Molecules 2011, 16, 6833-6843.

10. Al-Amiery, A.A.; Musa, A.Y.; Kadhum, A.H.; Mohamad, A. The Antioxidant Activity of New Coumarin Derivatives. Int. J. Mol. Sci. 2011, 12, 5757-5761.

11. Kadhum, A.H.; Al-Amiery, A.A.; Sikara, M.; Mohamad, A. Synthesis, Structure elucidation and DFT studies of new thiadiazoles. Int. J. Phys. Sci. 2011, 6, 6692-6697.

12. Al-Amiery, A.A.; Kadhum, A.H.; Aday, H.; Al-Majedy, Y.; Al-Temimi, A.; Mohamad, A.; Al-Bayati, R. Co-crystal structure of mixed molecules. Int. J. Phys. Sci. 2012, 7, 1564-1570.

13. Jones, G. Organic Reactions; John Wiley \& Sons: New York, NY, USA, 1967; Volume 15, pp. 204-599.

14. Tuyen, N.; Van, S.; Norbert, K. Synthesis of coumarins by ring-closing metathesis using Grubbs' catalyst. Tetrahedron Lett. 2003, 44, 4199-4201.

15. Su-Jin, P.; Jong-Cheol, L.; Kee-In, L. A Facile Synthesis of 4-Hydroxycoumarin and 4-Hydroxy-2-quinolone Derivatives. Bull. Korean Chem. Soc. 2007, 28, 1203-1205.

16. Al-Amiery, A.A.; Al-Majedy, K.; Abdulreazak, H.; Abood, H. Synthesis, characterization, theoretical crystal structure and antibacterial activities of some transition metal complexes of the thiosemicarbazone (Z)-2-(pyrrolidin-2-ylidene)hydrazinecarbothioamide. Bioinorg. Chem. Appl. 2011, 2011, 1-6.

17. Kadhum, A.; Wasmi, B.; Mohamad, A.; Al-Amiery, A.A. Takriff MS Preparation, characterization, and theoretical studies of azelaic acid derived from oleic acid by use of a novel ozonolysis method. Res. Chem. Inter. Med. 2012, 38, 659-668.

18. Al-Amiery, A.A.; Al-Majedy, Y.K.; Ibrahim, H.H.; Temimi, A.A. Antioxidant, antimicrobial, and theoretical studies of the thiosemicarbazone derivative Schiff base 2-(2-imino-1methylimidazolidin-4-ylidene) hydrazinecarbothioamide (IMHC). Org. Med. Chem. Lett. 2012, 2 , $1-7$.

19. Al-Amiery, A.A.; Kadhum, A.; Mohamad, A. Antifungal and Antioxidant Activities of Pyrrolidonethiosemicarbazone Complexes. Bioinorg. Chem. Appl. 2012, 2012, 1-5. 
20. Al-Amiery, A.A. Synthesis and antioxidant, antimicrobial evaluation, DFT studies of novel metal complexes derivate from Schiff base. Res. Chem. Intermed. 2012, 38, 745-759.

21. Al-Amiery, A.A. Antimicrobial and Antioxidant Activities of New Metal Complexes Derived from (E)-3-((5-phenyl-1,3,4-oxadiazol-2-ylimino)methyl)naphthalen-2-ol. Med. Chem. Res. 2012, in press.

22. Prasad, K.; Kumar, L.; Shekar, S.; Prasad, M.; Revanasiddappa, H. Oxovanadium complexes with bidentate N, O ligands: Synthesis, characterization, DNA binding, nuclease activity and antimicrobial studies. Chem. Sci. J. 2011. 12, 1-10.

23. Thangadurai, T.; Natarajan, K. Mixed ligand complexes of ruthenium(II) containing $\alpha, \beta$ unsaturated- $\beta$-ketoamines and their antibacterial activity. Transit. Met. Chem. 2001, 26, 500-504.

24. Dharmaraj, N.; Viswanathamurthi, P.; Natarajan, K. Ruthenium(II) complexes containing bidentate Schiff bases and their antifungal activity. Transit. Met. Chem. 2001, 26, 105-109.

25. Daw, Z.Y.; EL-Baroty, G.S.; Mahmoud, A.E. Inhibition of Aspergillus parasiticus growth and aflatoxin production by some essential oils. Chem. Mikrobiol. Technol. Lebensm. 1994, 16, 129-135.

26. Myiut, S.; Daud, W.R.W.; Mohamed, A.B.; Kadhum, A.A.H. Gas chromatographic determination of eugenol in ethanol extract of cloves. J. Chromatogr. Biomed. Appl. 1996, 676, 193-195.

Sample Availability: Samples of the compounds . Ethyl 2-((2-oxo-2H-chromen-4-yl)oxy)acetate (2), 2-(2-Oxo-2H-chromen-4-yloxy)acetohydrazide (3), 2-(2-(2-Oxo-2H-chromen-4-yloxy)acetyl)- $\mathrm{N}$ phenylhydrazinecarbothioamide (4), 4-((5-Mercapto-4-phenyl-4H-1,2,4-triazol-3-yl)methoxy)-2Hchromen-2-one (5) and 4-((5-(Phenylamino)-1,3,4-thiadiazol-2-yl)methoxy)-2H-chromen-2-one (7), are available from the authors.

(C) 2012 by the authors; licensee MDPI, Basel, Switzerland. This article is an open access article distributed under the terms and conditions of the Creative Commons Attribution license (http://creativecommons.org/licenses/by/3.0/). 